\title{
Research Paper Study on capital investment decisions and impact of capital structure on profitability of rice milling firms
}

\section{S. SELVANAYAKI AND S.D. SIVAKUMAR}

See end of the paper for authors' affiliations

Correspondence to :

S. SELVANAYAKI

Department of

Agricultural and Rural

Management, Tamil Nadu

Agricultural University,

COIMBATORE (T.N.) INDIA

Email:selviarm@tnau.ac.in

Paper History :

Received : 14.08 .2014

Revised : 30.12.2014;

Accepted : 16.01 .2015
ABSTRACT : The study was taken up to assess the capital investment decision making practices adopted by the rice milling firms and to analyse the impact of capital structure on profitability. Primary data on financial management practices were collected using interview schedule and financial data were obtained from the records maintained by the firms. The source of information for new investments in technology, discounted and undiscounted capital budgeting techniques used in the decision making process and future investment options for the firms were assessed in the study. The debt equity ratio during the study period was $2.13: 1$. Leverage and modernisation had a significant positive relationship with profitability of the firms.

KEY WORDS : Capital structure, Profitability, Leverage

HOW TO CITE THIS PAPER : Selvanayaki, S. and Sivakumar, S.D. (2015). Study on capital investment decisions and impact of capital structure on profitability of rice milling firms. Internat. Res. J. Agric. Eco. \& Stat., 6 (1) : 49-53. 